$\underline{\text { Tajdid: Jurnal Pemikiran Keislaman dan Kemanusiaan }}$

Vol. 3 No. 2 Oktober 2019

\title{
METODE AL-ALBANI DALAM UJI VALIDITAS HADIS RIWAYAT MUDALLIS \\ (Kritik atas Kritik Kamaruddin Amin)
}

\begin{abstract}
M. Syukrillah
Sekolah Tinggi Ilmu al-Quran (STIQ) Bima

Email: syukri.mbojo@gmail.com

Abstrak

Dalam beberapa karya ilmiahnya Kamaruddin Amin mengkritik metode yang digunakan al-Albani dalam menguji validitas hadis yang diriwayatkan oleh perawi mudallis. Implikasi metode al-Albani dalam menyeleksi validitas hadis para mudallisin dinilai bisa berdampak pada penda'ifan banyak hadis yang selama ini dinilai sahih oleh para ulama hadis. Tulisan ini menguji kembali argumen yang diajukan oleh Kamaruddin Amin untuk mengkritik pemikiran al-Albani dengan mengumpulkan pendapat dan hasil kerja uji validitas hadis karya al-Albani. Hasilnya menunjukkan bahwa terdapat kesenjangan (gap) antara kritik Kamaruddin Amin atas metode al-Albani dalam menentukan validitas hadis mudallas baik secara teori maupun praktek al-Albani sendiri. Kamaruddin Amin berkesimpulan bahwa dalam melakukan otentifikasi hadis, al-Albani sangat setia kepada metodologi sarjana Muslim tradisional. Namun demikian, metode yang digunakannya dalam menentukan otentisitas hadis terlalu umum.
\end{abstract}

Kata Kunci: Validitas Hadis, Mudallis, Hadis Mudallas, al-Albani

\section{Pendahuluan}

amaruddin Amin ${ }^{1}$ adalah salah seorang di antara peneliti hadis Indonesia
yang mengusung wacana kritis dalam diskursus hadis. Karya-karya ilmiah
Kamaruddin Amin di bidang hadis mempresentasikan kegelisahan

\footnotetext{
${ }^{1}$ Kamaruddin Amin lahir di Bontang 5 Januari 1969. Ia lulus Fakultas Adab, IAIN (sekarang UIN) Alauddin Makassar jurusan Bahasa dan Sastra Arab tahun 1994. Dengan beasiswa dari AFRC (Asia Foundation for Research and Consultative), Ia melanjutkan pendidikan pada jurusan Islamic studies di Rijks Universiteit te Leiden, Belanda. Di kampus ini, Kamaruddin dibimbing oleh para ilmuwan seperti G.H.A. Juynboll. Kamaruddin Amin meraih gelar Master of Art (MA) pada tahun 1998 dan menjadi lulusan terbaik setelah menyusun tesis dengan judul The Authenticity of Hadith; A Reconsideration of the Reliability of Hadith Transmission.Dengan beasiswa dari DAAD (Deutscher Akademischer Austausch Dienst) Jerman, ia melanjutkan pendidikan doktoralnya di Rheinischen Friedrich Wilhelms Universitaet Bonn Jerman dan lulus tahun 2005 dengan disertasi berjudul The Reliability of Hadith Transmission-A Reexamination of Hadith-Critical Methods yang dibimbing oleh Prof. Dr. Stefan Wild dan Prof. Dr. Harald Motzki. Ia meraih gelar guru besar ilmu hadis ('ulum al-hadith) pada Fakultas Adab dan Humaniora UIN Alauddin Makassar pada 29 Desember 2010 dengan pidato berjudul "Western Methods of Dating vis-a-vis 'Ulum al-Hadith: Refleksi Metodologis atas Diskursus Kesarjanaan Hadis Islam dan Barat”. Saat ini beliau menjabat sebagai Direktur Jendral Pendidikan Islam Kementrian Agama RI. Lihat Latifah Ulfa, "Lebih Dekat dengan Dr Phil Kamaruddin Amin MA”, 23 Juni 2010 dalam http://uin-alauddin.ac.id/uin-415-.html. Diakses 27 November 2016, Kamaruddin Amin, Menguji Kembali Keakuratan Metode Kritik Hadis (Jakarta: Penerbit Hikmah, Cet. 1, 2009),512, Kamaruddin Amin. "Western Methods of Dating...”, 40
} 
intelektual dan perhatian (concern) yang mendalam khususnya terhadap permasalahan otentisitas hadis dan upaya merekonstruksi asal-usul kesejarahannya serta masalah reliabilitas metodologi otentifikasi hadis. Dalam konteks permasalahan reliabilitas metodologi otentifikasi hadis, Kamaruddin Amin mengkritik sejumlah pemikiran para sarjana hadis di antaranya Muhammad Nasiruddin al-Albani. ${ }^{2}$ Dalam tulisannya untuk Jurnal Islamic Law and Society pada tahun 2004 dengan judul "Nasiruddin al-Albani on Muslim Sahih: A Critical Study on his Method", Kamaruddin Amin mengulas dan mengkritisi metode kritik hadis yang digunakan alAlbani. Kamaruddin menganalisa salah satu hadis dari Sahih Muslim yang dilemahkan al-Albani dalam Kitab Silsilah al-Ahadith al-Dha'ifah wa al-Mawdhu'at disebabkan masalah mu'an'an dari perawi mudallis bernama Abu al-Zubair. ${ }^{4}$

Hasil penelitian tersebut juga disebutkan di sertai perbandingan dengan metode Hasan bin 'Ali al-Saqqaf dalam disertasi doktoralnya yang berjudul The Reliability of Hadith Transmission-A Reexamination of Hadith-Critical Methods yang diajukan kepada Rheinischen Friedrich Wilhelms, Universitas Bonn Jerman. Disertasi ini kemudian diterjemahkan dan diterbitkan dalam bentuk buku berjudul "Menguji

\footnotetext{
${ }^{2}$ Nama lengkapnya adalah Muhammad Nashiruddin bin Nuh bin Adam al-Najati al-Albani (w. 1420 H/1999 M). Sementara nama panggilan sehari-hari yang akrab (kunyah) untuknya adalah Abu 'Abd al-Rahman (anak pertamanya bernama 'Abd al-Rahman) dan akrab di telinga umat Islam dengan nama Shaikh al-Albani, sedangkan al-Albani sendiri adalah penyandaran terhadap negara asalnya yaitu Albania. Al-Albani dilahirkan pada tahun $1332 \mathrm{H}$ atau bertepatan dengan tahun $1914 \mathrm{M}$ di Kota Askhodera (Shkoder), sebuah distrik pemerintahan di Albania. Ia mempelajari ilmu hadis secara otodidak. Karya-karyanya mencapai lebih dari 200 buah buku, yang kecil maupun yang besar (tebal), bahkan ada yang berjilid-jilid, yang lengkap maupun yang belum, yang sudah dicetak maupun yang masih berbentuk manuskrip. Karya-karya al-Albani di bidang hadis antara lain; Silsilah al-Ahadith alSahihah wa Shai'un min Fiqhiha wa Fawaidiha (9 jilid), Silsilah al-Ahadith al-Daifah wa alMaudu'ah wa Atharuha Al-Sayyi' fi al-Ummah (14 jilid), Irwa' al-Ghalil (8 jilid), Sahih dan Da'if Jaami' al-Saghir wa Ziyadatihi, Sahih Sunan Abi Dawud dan Da'if Sunan Abi Dawud, Sahih Sunan al-Tirmidhi dan Da'if Sunan al-Tirmidzi, Sahih Sunan al-Nasa'i dan Da'if Sunan al-Nasa'i, Sahih Sunan Ibn Majah dan Da'if Sunan Ibn Majah, dan lain-lain. Lihat Kamaruddin Amin, Nasiruddin AlAlbani on Muslim's Sahih: A Critical Study of his Method (Jurnal Islamic Law and Society, 2004), 149, Ibrahim Abu al-Shadi, al-Ikhtiyarat al-Fiqhiyyah li al-Imam al-Albani (Kairo; Dar al-Ghadd alJadid, Cet.1, 1427 H/2006 M), 9, Abdurrahman bin Muhammad al-'Aizuri, Juhud al-Albani fi alHadith Riwayatan wa Dirayatan (Riyad: Maktabah al-Rushd, Cet. 1, 1425 H), 33, Muhammad bin Ibrahim al-Shaibani, Hayah al-Albani wa Atharuh wa Thana al-'Ulama 'alaih (t.tp: Maktabah alSaddawi, cet. $1,1407 \mathrm{H})$, 44-75

${ }^{3}$ Kamaruddin Amin, Nasiruddin Al-Albani On Muslim's Sahlh: A Critical Study Of His Method (Jurnal Islamic Law And Society 11,2 Koninklijke Brill Nv, Leiden, 2004), 149-176

${ }^{4}$ Idri mendefinisikan hadis mudallas secara istilah adalah hadis yang diriwayatkan dengan cara yang diperkirakan bahwa hadis tersebut tidak bercacat. Periwayat yang menyembunyikan cacat disebut al-mudallis, hadisnya disebut al-mudallas, dan perbuatan menyembunyikan (cacat hadis) disebut al-tadlis. Idri, Studi Hadis (Jakarta: Kencana Predana, cet. 2, 2013), 210
} 
Kembali Keakuratan Metode Kritik Hadis" ${ }^{, 5}$ dan juga dipublikasikan dalam makalah berjudul "Problematika Ulumul Hadis, Sebuah Upaya Pencarian Metodologi Alternatif". ${ }^{6}$ Demikian pula disampaikan dalam pidato pengukuhan guru besarnya di bidang Ilmu Hadis Fakultas Adab dan Humaniora UIN Alauddin Makassar tanggal 29 Desember 2010 berjudul "Western Methods of Dating vis-a-vis Ulumul Hadis: Refleksi Metodologis atas Diskursus Kesarjanaan Hadis Islam dan Barat"7

\section{Kritik Kamaruddin Amin Terhadap Al-Albani Tentang Uji Validitas Hadis Riwayat Mudallis}

Kamaruddin Amin dalam jurnal ilmiah internasional Islamic Law and Society 11 (2004) mendiskusikan metode al-Albani dalam menentukan otentisitas dan kelemahan hadis yang terdapat dalam Sahih Muslim. Ia menggunakan perspektif ilmu hadis tradisional ('ulum al-hadith) dan perspektif metodologi sarjana non-Muslim yaitu dengan penanggalan (dating). ${ }^{8}$ Identifikasi metode al-Albani dengan menganalisis hadis tentang "sapi" yang merupakan salah satu hadis dalam Sahih Muslim yang dilemahkan oleh al-Albani. ${ }^{9}$ Hadis tersebut yaitu:

Ahmad bin Yunus menceritakan kepada kami, Zuhair menceritakan kepada kami, Abu al-Zubair menceritakan kepada kami dari ('an) Jabir berkata, Rasulullah shallallahu 'alaihi wasallam bersabda: "Jangan kamu menyembelih kurban kecuali seekor sapi yang cukup umur, kecuali kalau sulit bagimu, maka sembelilah seekor domba.'

\footnotetext{
${ }^{5}$ Kamaruddin Amin, Menguji Kembali Keakuratan Metode Kritik Hadis (Jakarta: Penerbit Hikmah, Cet. 1, 2009)

${ }^{6}$ Kamaruddin Amin, Western Methods Of Dating Vis-à-vis Ulumul Hadis..., 32. Kamaruddin Amin, "Problematika Ulumul Hadis Sebuah Upaya Pencarian Metodologi Alternatif", dalam://www.ditpertais.net/annualconference/ancon06/makalah /Makalah\%20Komaruddin.doc. (27 Desember 2014), 4 dan "Problematika Ulumul Hadis Sebuah Upaya Pencarian Metodologi Alternatif”, http://profkamaruddin.blogspot.co.id/p/blog-page_2.html (diakses 25/09/2015)

${ }^{7}$ UIN Online, "Western Methods Of Dating Vis-à-vis Ulumul Hadis", dalam http://www.uinalauddin.ac.id/uin-982-.html (29 Desember 2014)

${ }^{8}$ Kamaruddin Amin, "Nasiruddin Al-Albani On Muslim's Sahih: A Critical Study Of His Method”, Jurnal Islamic Law And Society 11,2 (Koninklijke Brill Nv, Leiden, 2004 ), 149-176. Studi tersebut disebutkan oleh Kamaruddin Amin dalam disertasi doktoralnya. Lihat Kamaruddin Amin, The Reliability of hadith Transmission - A Reexamination of Hadith-Critical Methods (Ph. D dissertation, Bonn Universitaet, 2005), 57-88.

${ }^{9}$ Kamaruddin memilih hadis tersebut karena hadis tersebut direkam, di antaranya, dalam Sahih Muslim, salah satu kitab koleksi hadis yang paling bergengsi. Kamaruddin Amin, Menguji Kembali..., 73

${ }^{10}$ Merujuk takhrij yang dilakukan oleh Kamaruddin Amin, hadis tersebut diriwayatkan oleh Muslim bin al-Hajjaj, al-Jami' al-Sahih, ed. Fu'ad Abd al-Baqi (Dar al-Kutub al-'Arabiyyah, 1374 H/1955 M), Kitab al-Dahaya 2:1, Abu Dawud, Sunan (Kairo, 1971), Kitab al-Dahaya, 5:1, Ibn Majah, dan al-Nasa'i. Kamaruddin Amin, Menguji Kembali..., 109. Catatan akhir nomor 14.
} 
Menurut Kamaruddin Amin, metode al-Albani dalam menentukan autentisitas dan kepalsuan sebuah hadis, terutama berdasarkan analisis pada isnad, dengan menggunakan informasi yang terdapat dalam kamus biografi. Ia menyimpulkan bahwa al-Albani menilai riwayat Abu al-Zubair dari Jabir tidak bersambung (ghair muttasil). Penilaian didasarkan alasan bahwa (1) para kritikus hadis menyifati Abu alZubair sebagai mudallis, (2) Abu al-Zubair tidak mengatakan secara ekspilisit apakah mendengar langsung dari Jabir, namun menggunakan lafal " 'an" (atas otoritas dari). al-Albani menurut Kamaruddin Amin menyimpulkan bahwa kebenaran setiap hadis yang diriwayatkan oleh Abu al-Zubair dari Jabir atau dari orang lain, yang menggunakan lafal "'an" dan sejenisnya, harus ditunda. Akan tetapi, al-Albani tidak meragukan riwayat Abu al-Zubair dari Jabir apabila diriwayatkan oleh al-Laith bin Sa'd, karena al-Laith mengklaim telah menerima dari Abu al-Zubair hanya hadis yang didengar oleh Abu al-Zubair dari Jabir. ${ }^{11}$

Kamaruddin Amin berkesimpulan bahwa dalam melakukan otentifikasi hadis, al-Albani sangat setia kepada metodologi sarjana Muslim tradisional. Namun demikian, metode yang digunakannya dalam menentukan otentisitas hadis terlalu umum. Kamaruddin Amin memisalkan al-Albani 'melemahkan' hadis hanya karena Abu al-Zubair dianggap telah melakukan tadlis. Penilaian terhadap Abu al-Zubair tidak didasarkan pada penelitian komprehensif terhadap biografi Abu al-Zubair, tidak juga pada studi analisis terhadap riwayat Abu al-Zubair, melainkan hanya berdasar pada penilaian para kritikus hadis seperti Abu Hatim, al-Dzahabi dan lain-lain. Padahal para kritikus hadis tidak secara bulat menilai negatif Abu al-Zubair. ${ }^{12}$ Dalam perspektif Kamaruddin tentang metode Al-Albani, bahwa penilaian seorang perawi sebagai mudallis merupakan jarh yang menjatuhkan ke-thiqah-an perawi.

Menurut penilaiannya, Al-Albani hanya bersandar pada penilaian beberapa ulama yang menilai negatif Abu al-Zubair. "Padahal para kritikus hadis tidak secara bulat menilai negatif Abu al-Zubair. Memang di antara mereka menganggapnya terpercaya (thiqah)". ${ }^{13}$ Dalam analisisnya atas hadis "la tadhbahu illa musinnatan", Kamaruddin berpendapat bahwa penilaian dari para ulama baik yang positif maupun yang negatif perlu dikumpulkan dan pendekatan kaidah jarh wa ta'dil digunakan untuk mendamaikan perbedaan penilaian ulama. Dalam kasus Abu al-Zubair, perbedaan pendapat para ulama dalam menilai Abu al-Zubair baik yang positif maupun negatif, perlu dikembalikan kepada 'ulum al-hadis. Menurut 'ulum al-hadis, apabila penilaian negatif dan positif dinisbatkan kepada satu perawi, maka prioritas

\footnotetext{
${ }^{11}$ Kamaruddin Amin, Menguji kembali.., 73-74

${ }^{12}$ Kamaruddin Amin, Menguji kembali.., 90-91

${ }^{13}$ Ibid., 91
} 
diberikan kepada penilaian yang negatif (al-jarh), dengan syarat penilaian tersebut dijelaskan. Jika tidak, maka penilaian positiflah yang diutamakan (al-ta'dil). Namun demikian, Kamaruddin Amin berpendapat bahwa teori ini tidak membantu dalam menentukan kualitas riwayat Abu al-Zubair. Menurutnya, tidak ada penilaian umum yang dapat diberlakukan kepada Abu al-Zubair. Setiap riwayat Abu al-Zubair harus dianalisis dan dikritisi menurut kualitasnya masing-masing. ${ }^{14}$

Menurut Kamaruddin Amin, penilaian lemah dari al-Albani terhadap hadis tersebut, yang didasarkan hanya pada penilaian negatif atas kepercayaan Abu alZubair, memiliki konsekwensi serius pada hadis-hadis lain, yang mungkin tidak disadari Albani. Dalam kasus Abu al-Zubair, metode al-Bani mengharuskan kita untuk mempertanyakan historisitas sedikitnya 125 hadis yang diriwayatkan oleh Abu al-Zubair dalam Sahih Muslim (jumlah tersebut berdasar pada jalur Abu al-Zubair Jabir dalam teks dalam Sahih Muslim). ${ }^{15}$ Di samping itu, Kamaruddin mempertanyakan sikap al-Albani yang tidak memasukkan riwayat al-Laith bin Sa'd dari Abu al-Zubair sebagai hadis lemah hanya karena klaim al-Laith telah meriwayatkan dari Abu al-Zubair hanya hadis-hadis yang didengarkannya langsung dari Jabir. Menurut penilaian Kamaruddin, kesimpulan al-Albani tersebut hanya didasarkan pada Ibn Hazm yang berkesimpulan sama. Sebab, al-Albani tidak menganalisis secara mendalam dan komprehensif jalur periwayatan al-Laith-Abu alZubair-Jabir. $^{16}$

Fakta yang diperoleh oleh Kamaruddin menunjukkan bahwa dari 27 hadis yang diriwayatkan al-Laith bin Sa'd dari Abu al-Zubair, hanya satu yang secara eksplisit menyatakan bahwa ia menerima langsung dari Jabir. Dalam kaitannya dengan sighat tahammul wa al-ada', Fakta ini menurut Kamaruddin menimbulkan masalah yang harus dijawab oleh al-Albani. Kalau al-Laith "mendengar" hadis tersebut langsung dari Jabir, sebagaimana diklaim al-Albani yang mengutip Ibn Hazm, mengapa Abu al-Zubair menggunakan kata "'an" di hampir semua riyawat alLaith yang direkam oleh para penghimpun hadis? Mengapa status Abu al-Zubair sebagai seorang mudallis yang periwayatannya harus ditolak atau ditunda kehujahannya hingga terbukti bahwa dia mendengar langsung dari informannyaberubah menjadi tidak mudallis ketika riwayat selanjutnya adalah al-Laith, meskipun istilah isnad tidak menunjukkan bahwa Abu al-Zubair mendengar hadis tersebut langsung dari informannya? ${ }^{17}$

\footnotetext{
${ }^{14}$ Kamaruddin Amin, Menguji kembali.., , 83-84

${ }^{15}$ Ibid

${ }^{16}$ Ibid., 79

${ }^{17}$ Ibid., 80
} 
Dalam artikelnya "Nasiruddin Al-Albani On Muslim's Sahih: A Critical Study Of His Method", berbagai problem tersebut semula dinilai oleh Kamaruddin Amin hanya sebagai kelemahan metodologis al-Albani. Namun, pada publikasi berikutnya seperti makalah dan pidato guru besarnya, Kamaruddin Amin secara eksplisit menyebutkan bahwa problem metodologis al-Albani maupun al-Saqqaf tersebut adalah kelemahan metodologis dari 'ulum al-hadith pada umumnya. ${ }^{18}$ Dalam hal ini karena al-Albani dinilainya sangat setia kepada metodologi sarjana Muslim tradisional ('ulum al-hadith) dalam melakukan otentifikasi hadis. ${ }^{19}$ Kamaruddin Amin menyimpulkan bahwa metode yang digunakan al-Albani terlalu global dan tidak komprehensif dalam menguji data biografis Abu al-Zubair. Menurutnya metode al-Albani berimplikasi negatif terhadap penurunan kualitas hadis. ${ }^{20}$

\section{Metode Al-Albani dalam Menyeleksi Validitas Hadis Mudallas}

Tentang rumusan kaidah untuk mendalami dan memahami sunnah (dari aspek validitasnya), al-Albani menyatakan "Kaidah ketiga; Menolak hadis mudallas. Tadlis terjadi dalam tiga bentuk yaitu tadlis isnad, tadlis al-shuyukh dan tadlis al-taswiyah. Hukum dari perawi yang divonis melakukan tadlis adalah tidak diterima (la yuqbal) walaupun dia perawi adil kecuali disebutkan secara tegas (eksplisit) menggunakan ungkapan tahdith (seperti haddathana, haddathani, sami'na, sami'tu)". ${ }^{21}$ Menurut alAlbani, kalau riwayat mudallis dari perawi tersebut thiqahyang tidak jelas status sama'-nya diakui sebagai hadis sahih, maka hal itu meniscayakan diterimanya riwayat-riwayat yang sanad-nya terputus (munqathi') dan mursal diterima juga sebagai hadis sahih. Sikap waspada terhadap riwayat mudallis yang tidak secara tegas (eksplisit) menggunakan ungkapan tahdiith dalam sighat al-ada'-nya ini dilatarbelakangi kekhawatiran bahwa informan riwayat perawi mudallis adalah seorang perawi yang lemah. Pengecualian diberikan bila perawi mudallis hanya

\footnotetext{
${ }^{18}$ Menurut Harald Motzki, hasil penelitian Kamaruddin Amin telah mengungkap problem banyaknya hadis yang tidak bisa dipercaya jika metode-metode klasik kritik hadis Islam ('ulum alhadith) diterapkan padanya dengan konsisten. Menurutnya, temuan-temuan Kamaruddin mempertegas simpulan bahwa para penghimpun awal koleksi-koleksi hadis semisal al-Bukhari dan Muslim tidak menerapkan kriteria kritik hadis klasik yang telah dikembangkan selama beberapa abad, suatu perkembangan yang mencapai kesempurnaannya di abad ke-13 bersamaan dengan ditulisnya Muqaddimah karya Ibn al-Shalah.Pengantar Dari Harald Motzki atas buku Kamaruddin Amin Menguji Kembali Keakuratan Metode Kritik Hadis yang diterbitkan oleh Penerbit Hikmah tahun 2009.. Lihat Kamaruddin Amin, Menguji Kembali.., vi-vii

${ }^{19}$ Kamaruddin Amin, Menguji Kembali Keakuratan Metode Kritik Hadis (Jakarta: Penerbit Hikmah, Cet. 1, 2009), 71-109

${ }^{20}$ Ibid, 171v mm.

${ }^{21} \mathrm{Abu}$ 'Abd al-Rahman Nasr al-Din al-Albani, Tamam al-Minnah fi al-Ta'liq 'ala Fiqh alSunnah, Vol. 1,(T.tp: Dar al-Rayah, cet.5, t.th), 18
} 
melakukan tadlis dalam periwayatan dari perawi thiqah mutqin. ${ }^{22}$ Sebelum penerapan kaidah umum dalam menyikapi hadis dari riwayat mudallis tersebut di atas, al-Albani berpendapat perlunya melihat berbagai sisi sebagai berikut:

Pertama, kepastian status mudallis dan adanya tindakan tadlis oleh sang perawi 'yang diklaim sebagai sebagai mudallis. Hal ini karena adanya perawi yang disebut sebagai mudallis padahal bukan. Contohnya adalah Laith bin Abi Salim. AlAlbani dalam Silsilah al-Dha'ifah berpendapat bahwa para imam ahli hadis tidak menvonisnya sebagai pelaku tindakan tadlis. ${ }^{23}$ Kedua, jenis tadlis yang dilakukan oleh mudallis. Hal ini karena adanya jenis tadlis yang tidak terpengaruh dan tidak terkait dengan sighat 'an'anah dalam sanad seperti pada kasus tadlis al-shuyukh. Contohnya ketika al-Albani dalam Kitab al-Tawaasul membahas perawi bernama 'Athiyah al-'Aufi. Ketiga, ukuran atau kuantitas tindakan tadlis. Hal ini karena ada perawi yang sangat sedikit melakukan tadlis sehingga diterima riwayat 'an'anah-nya. Apabila seorang perawi diketahui banyak melakukan tindakan tadlis, maka riwayat 'an'anah-nya tertolak. ${ }^{24}$

Menurut al-Albani, penilaian tentang keadaan seorang perawi mudallis, apakah ia banyak atau sedikit melakukan tadlis merupakan pendapat yang didasari hasil penelitian dan ijtihad. Dalam hal ini bisa terjadi perbedaan pendapat di antara ulama hadis. Jika seorang ahli hadis menilai bahwa perawi mudallis tertentu banyak melakukan tadlis, maka dalam pandangan ahli hadis tersebut riwayat mu'an'an dari mudallis tersebut tertolak. Demikian pula sebaliknya. Di antara beberapa contoh kasus hal tersebut adalah penilaian atas al-Hasan al-Basri, al-Zuhri, dan Talhah bin Nafi'. Al-Hasan al-Basri, menurut Ibn Hajar dalam Thabaqah al-Mudallisiin (nomor indeks perawi 29), ia termasuk di level kedua sebagai perawi yang sedikit melakukan tadlis, sementara al-Albani menilainya termasuk di level ketiga sebagai perawi yang banyak melakukan tadlis. Al-Zuhri dinilai oleh Ibn Hajar berada di level ketiga yang banyak melakukan tadlis sehingga tidak diterima riwayat mu'an'an-nya, sementara al-'Alaa'I dan al-Albani menempatkannya pada level kedua sehingga diterima riwayat mu'an'an-nya. Adapun Thalhah bin Nafi' ditempatkan oleh Ibn Hajar dalam

\footnotetext{
${ }^{22}$ Lihat komentar al-Albani dalam Muhammad bin Hibban al-Busti, al-Ta'liqat al-Hisaan 'ala Sahih Ibn Hibban wa Tamyiz Saqimih min Sahiihih wa Shadh min Mahfuzih, vol.1 (Jeddah: Dar Ba Wazir li al-Nashr wa al-Tawzi', cet.1, 1424 H/2003 M), 121

${ }^{23}$ al-Albani, Silsilah al-Ahadiith al-Da'ifah wa al-Mawdu'ah wa Atharuha al-Sayyi fi alUmmah, vol. 11 (Riyadh: Dar al-Ma'arif, cet.1, 1412 H/1996 M), 559

${ }^{24} \mathrm{Abu}$ Yahya Zakariya bin Ghulam Qadir, Al-Albani wa Manhaj al-Aimmah al-Mutaqaddimin fi 'Ilm al-Hadith (Riyadh: Maktabah al-Ma'arif, cet.1, 1431 H/2010 M), 49-50
} 
Tabaqah al-Mudallisin (nomor indeks 39) pada level ketiga yang tidak diterima riwayat $m u^{\prime}$ 'an'an-nya sementara al-Albani mengakui validitasnya. ${ }^{25}$

Kelima, Ada penguat dari jalur sanad lain yang menunjukkan adanya tahdis (penerimaan hadis secara langsung) yang menafikan al-tadlis. Hal ini sebagaimana penilaian al-Albani terhadap riwayat Abu al-Jubair 'an Jabir dalam Musnad Ahmad (3/367) dan al-Thahawi (1/317) dari kisah 'Abdullah bin Rawahah yang diutus kepada Yahudi Khaibar. Al-Albani menilai bahwa seluruh perawi dalam sanad-nya thiqat.Namun, masalahnya hanya pada 'an'anah yang dilakukan Abu al-Jubair dari Jabir. Namun, pada jalur sanad lain dalam riwayat Ahmad (3/296) dari perawi Ibn Juraij berkata: "Abu Jubair mengabarkan kepadaku (akhbarani) bahwa dia mendengar riwayat itu Jabir bin Abdillah". Demikian pula dengan adanya hadis lain sebagai shahid yaitu riwayat Ibn 'Umar yang diriwayatkan oleh Ahmad (2/24) dengan perawi yang seluruhnya thiqat kecuali Abdullah bin 'Umar al-'Umari al Makburi yang lemah hafalannya (su'u al-hifz) akan tetapi memiliki taabi' yaitu 'Abdullah bin Nafi'dalam riwayat al-Thahawi (1/316) yang lemah juga. Namun, alAlbani menilai riwayat-riwayat ini saling menguatkan satu dengan yang lain. ${ }^{26}$

Pada hadis nomor indeks 345 dalam Silsilah al-Shahihah: "Istakthiruw min alni'al...". Hadis tersebut menurut penelitian al-Albani adalah riwayat Muslim (6/153), Abu Dawud (4133), Ahmad (3/337, 360), al-Khatib al-Baghdadi dalam Tarikh Baghdad (3/426) dari jalur Abu al-Zubair 'an Jabir. Menurut al-Albani hadis tersebut sahih walaupun dalam sanad-nya Abu al-Jubair menggunakan ungkapan " an" dari Jabir. Hal ini karena hadis tersebut memiliki shawahid (penguat dari level perawi pertama yaitu sahabat Nabi) yang menguatkan kesahihannya. Di antaranya adalah hadis berkualitas hasan dari 'Imran bin Husain yang dikeluarkan al-'Uqaili (230) dan al-Khatib (9/404-405) dari jalur Muja'ah bin al-Zubair al-Asadi yang mendengar dari al-Hasan 'Imran bin Husain. Demikian pula, syahid dari hadis 'Abdullah bin 'Amr yang dikeluarkan oleh al-Thabrani dalam Al-Awsath walaupun dalam sanad-nya terdapat Isma'il bin Muslim al-Makki yang dha' $i f^{27}$

Demikian pula penilaian al-Albani atas hadis riwayat Muslim (6/114), "Amara Rasulullah shalla Allahu 'alaih wa sallam bi la'qi al-asabi' wa alshahfah...". Hadis tersebut diriwayatkan dari Sufyan dari Abu al-Jubair dari Jabir dengan $m u$ 'an'an. Namun, al-Albani menilainya sahih karena adanya mutaba'ah dari Ibn Jubair yang menegaskan bahwa dia mendengar (akhbarani) Abu al-Jubair yang

${ }^{25}$ ibid, 41

${ }^{26}$ al-Albani, Irwa' al-Ghalil fi Takhrij Ahadith Manar al-Sabil,Vol. 3 (Beirut: al-Maktab alIslami, cet. 2, $1405 \mathrm{H} / 1985 \mathrm{M}), 281$

${ }^{27}$ al-Albani, Silsilah al-Ahadith al-Shahihah wa Shai' min Fighiha wa Fawa'idiha, vol. 1 (Riyad\}: Maktabah al-Ma'arif, cet.1, 1415 H/1995 M), 679-680 
berkata bahwa ia mendengar (annahu sami'a) Jabir yang berkata (sami'tu Rasulallah..), kemudian menyebut lafal hadis tersebut. Hadis tersebut menurut alAlbani, diriwayatkan Abu 'Awanah, al-Nasa'I dan Ibn Hibban dengan sanad yang sahih. Demikian pula hadis riwayat Muslim tersebut memiliki shahid dari hadis Anas bin Malik dan Abu Hurairah yang menguatkan validitas periwayatan Abu al-Jubair dari Jabir tersebut. ${ }^{28}$ Al-Albani menilai sahih hadis mu'an'an dari perawi mudallis jika terdapat penegasan al-sama' pada jalur lain. Seperti pembahasan al-Albani mengenai riwayat Ibn Juraij dari Abu al-Zubair 'an Jabir dalam hadis riwayat Muslim (4/153). Dalam hadis tersebut Abu al-Zubair tidak menegaskan al-sama'-nya dari Jabir, namun dalam sanad yang dicantumkan oleh al-Thahawi dalam Mushkil alAthar (4/147) terdapat adanya penegasan al-sama' Abu al-Zubair yang mendengar dari Jabir dengan jalur sanad 'Abu 'Ashim dari Ibn Juraij dari Abu al-Jubair. Oleh karena itu, hadis ini dinilai sahih oleh al-Albani. ${ }^{29}$

Dengan data di atas, terungkap bahwa al-Albani menentukan status validitas riwayat hadis mu'an 'an dari perawi mudallis berdasarkan perincian status dan kondisi perawi mudallis tersebut dan keadaan periwayatannya. Metode al-Albani tersebut sejalan dengan pemikiran dan metode yang dikenal dalam 'ulum al-hadith. ${ }^{30}$ Pensahihan hadis mudallis juga dilakukan oleh al-Albani melalui pendekatan makna hadis atau kritik matan. Contohnya dalam penelitian al-Albani tentang hadis "Idha qumtum ila al-shalah fala tasbiquw qariakum bi al-ruku' wa al-sujud...”. Hadis ini diriwayatkan al-Bazzar dalam Musnad-nya dari jalur al-Hasan al-Basri yang mudallis dan menggunakan ungkapan 'an dalam sanadnya. Namun, hadis tersebut maknanya sahih jika dikompilasikan dengan hadis-hadis lainnya sehingga dicantumkan oleh alAlbani dalam Silsilah al-Shahihah. ${ }^{31}$

Contoh lain adalah hadis yang dinilai al-Albani sebagai hadis sahih dan dicantumkan dalam Silsilah al-Sahihah nomor indeks 3086 yaitu hadis yang diriwayatkan oleh Muslim (7/7) yang berbunyi "Ala la yabitanna rajulun inda imraatin thaibin illa an yakuna nakihan aw mahraman. ${ }^{32}$ Hadis tersebut melalui jalur

${ }^{28}$ Ibid.,vol. 1, 746-747, Irwa al-Ghalil, vol. 7, 31-33

${ }^{29}$ Ibid., vol. 1, 682-683. Hadis nomor indeks 347

${ }^{30}$ Metode dalam 'ulum al-hadith yang digunakan oleh mayoritas ulama hadis disebutkan oleh Abdullah bin Yusuf al-Juda'i, Tahrir 'Ulum al-Hadith, Vol. 2 (Beirut: Muassasah al-Rayyan, cet. 1, 1424 H/2003 M), 970-989, Awwad al-Khalaf, Riwayat alMudallisin fi Shahih al-Bukhari: Jam'uha-Takhrijuha-al-Kalam 'alaiha. (ttt: Dar al-Basyair al-Islamiyah, $\mathrm{tt}), 26-31$

${ }^{31}$ Ibid., vol. 3, 381. Hadis nomor indeks 1393

${ }^{32}$ Hadis tersebut disebutkan juga oleh Alba $>$ ni $>$ telah diriwayatkan oleh Ibn Abi Shaibah dalam al-Musannaf (4/409) dan al-Nasa'I dalam Sunan al-Kubra (2/386/9215), dan lain-lain. Muhammad Nasir al-Din al-Albani, Silsilah al-Ahadith al-Shahihah.., vol. 7, 225 
sanad Hushaim akhbarana Abu al-Zubair 'an Jabir. Menurut al-Albani seluruh jalur sanad yang ada tidak menyebutkan secara tegas al-sama' dari Abu al-Zubair. Demikian pula tidak ada yang melalui riwayat al-Laith dari Abu al-Zubair. Namun demikian, hadis tersebut dinilai sahih oleh al-Albani karena adanya kesesuaian makna dengan hadis yang diriwayatkan oleh Abdurrahman bin Jubair bahwa 'Abdullah bin 'Amr bin al-'Ash : 'Anna nafaran min Bani Hasyim... hadis riwayat Muslim (7/8), alNasa'I dalam al-Kubra nomor indeks 9217 dan Fada'il al-Shahabah nomor indeks 284, Ibn Hibban nomor indeks 5585, al-Baihaqi (7/90), dan Ahmad (2/171, 186, 213). ${ }^{33}$ Contoh-contoh metode al-Albani dalam menilai riwayat mu'an'an Abu alZubair dari Jabir seperti di atas cukup banyak. Hal ini lebih lanjut bisa dilihat dalam Silsilah al-Ahadits al-Shahihah pada pembahasan hadis nomor indeks 568, 817, $1100,1159,1217,1402,1516,1549,1783,1787,2137,2171,2206,2368$, dan lainlain.

Dengan data temuan di atas, klaim Kamaruddin Amin bahwa menurut alAlbani, "Riwayat Abu al-Zubair dari Jabir tidak bersambung (ghair muttashil) dengan alasan bahwa (1) para kritikus hadis menyifati Abu al-Zubair sebagai mudallis, (2) dia tidak mengatakan secara ekspilisit apakah mendengar langsung dari Jabir, namun menggunakan lafal " 'an" (atas otoritas dari)", tidak berlaku mutlak dan tidak dapat digeneralisasi. Dengan mengumpulkan data yang lebih banyak, rumusan metode al-Albani dalam menilai riwayat para mudallis menjadi lebih komprehensif dan tepat. Apa yang dipraktekan al-Albani tidak bertentangan dengan konsep yang dikenal oleh para ulama hadis. Demikian pula pendapat Kamaruddin Amin yang tidak sepenuhnya tepat, ${ }^{34}$ adalah klaim bahwa "metode al-Albani dalam menentukan autentisitas dan kepalsuan sebuah hadis tertentu, terutama berdasarkan analisis pada isnad, dengan menggunakan informasi yang terdapat dalam kamus biografi". Dari data yang ada bahwa penggunaan informasi tidak menegasikan adanya upaya telaah kritis dan ijtihad oleh al-Albani terhadap data yang ada. Demikian pula al-Albani melakukan perbandingan riwayat untuk menemukan indikasi (qarinah) baik yang bersifat mengafirmasi maupun menegasikan kemungkinan tindakan tadlis dan implikasi pen-dha 'if-annya, bukan sekedar mencukupkan dengan data biografi.

\footnotetext{
${ }^{33}$ Ibid.,vol. 7, 225-227

${ }^{34}$ Penulis menilai "tidak sepenuhnya tepat", karena di samping pendapat tersebut ada yang tidak benar. Namun, ada pula yang benar, yaitu adanya penilaian dha 'if oleh al-Albani atas hadis-hadis dalam berbagai kitab hadis karena masalah perawi mudallis. Di antaranya bisa dilihat dalam hadis nomor indeks 65, 84, 120, 145, 165, 174, 187, 193, 198 dan sebagainya. Lihat Nashiruddin al-Albani, lihat Silsilah al-Ahadith al-Dha'ifah wa al-Mawdu'ah wa Atharuha al-Sayyi' fi al-Ummah, Vol. 1 (Riyad: Dar al-Ma'arif, cet. 1, 1412 H)
} 
Kamaruddin berpendapat bahwa penilaian lemah dari Albani terhadap hadis mu'an'an Abu al-Zubair dari Jabir yang didasarkan hanya pada penilaian negatif atas kepercayaan Abu Zubair, memiliki konsekwensi serius pada hadis-hadis lain, yang mungkin tidak disadari Albani. Menurut Kamaruddin bahwa metode Albani mengharuskan kita untuk mempertanyakan historisitas sedikitnya 125 hadis mu'an 'an yang diriwayatkan oleh Abu Zubair dari Jabir dalam Sahih Muslim. ${ }^{35}$ Namun pendapat Kamaruddin Amin tersebut tidak sejalan dengan metode al-Albani. AlAlbani tidak melemahkan hadis hanya karena melihat status Abu al-Zubair yang mudallis dan ungkapan 'an'anah yang digunakannya. Namun, al-Albani mengumpulkan jalur sanad lain yang dari Abu al-Zubair yang menyebutkan secara tegas adanya al-sama'. Demikian pula al-Albani meneliti kemungkinan adanya mutaba'ah dan syawahid hadis tersebut. Bahkan pendekatan perbandingan dengan matan hadis lain yang dapat menguatkan validitas hadis dari mudallis tersebut. Hal tersebut selaras dengan metode pensahihan hadis dengan berkumpulnya banyak jalur periwayatan walaupun nilai satuan masing-masing (infirad) lemah (dha'if). Pendapat ini, menurut al-Albani populer di kalangan ulama. ${ }^{36}$

Walaupun dalam ijtihadnya, al-Albani men-dha'if-kan hadis "Sapi" dalam Sahih Muslim sebagaimana yang dirujuk oleh Kamaruddin Amin. Namun, al-Albani tidak menilai dha' if seluruh hadis mu'an'an Abu al-Zubair dari Jabir. ${ }^{37}$ Banyak hadis mudallas dari Abu al-Zubair dari Jabir dalam Shahih Muslim lainnya yang disahihkan oleh al-Albani dengan metode tersebut di atas dan dicantumkan dalam Silsilah alShahihah yang di antara hadisnya yaitu hadis nomor indeks 345, 1516, 3086, 1549, 2171, 3530. Kamaruddin Amin juga mengajukan fakta pensahihan oleh al-Albani atas riwayat al-Laith bin Sa'd dari Abu al-Zubair yang menunjukkan bahwa dari 27 hadis yang diriwayatkan al-Laith bin Sa'd dari Abu al-Zubair, hanya satu yang secara eksplisit menyatakan bahwa ia menerima langsung dari Jabir. Fakta ini menimbulkan

\section{${ }^{35}$ Ibid.}

${ }^{36}$ Al-Albani menegaskan bahwa kaidah tersebut tidak mutlak, namun para muhaqqiqin (peneliti hadis membatasinya dengan syarat tertentu seperti perawi bukan di-jarh karena tertuduh dalam kejujuran dan agamanya. Lihat 'Isam Musa Hadi, al-Rawd al-Dani fi al-Fawa'id al-Hadithiyah li al- 'Allamah Nashir al-Din al-Albani (Umman: al-Maktabah al-Islamiyah, cet.1, 1423 H), 28

${ }^{37}$ Kamaruddin memilih hadis tersebut karena hadis tersebut direkam, di antaranya, dalam Sahih Muslim, salah satu kitab koleksi hadis yang paling bergengsi. Kamaruddin Amin, Menguji Kembali..., 73. Menurut penulis, pen-dha'if-an tersebut adalah bagian dari ijtihad masing-masing ulama hadis yang bisa menghasilkan pendapat berbeda tentang sahih atau tidaknya suatu hadis. Sebagaimana pendapat Ibn Shalah, walaupun secara teoritis, syarat-syarat sahih pada umumnya disepakati oleh ulama hadis. Namun, rincian dan aplikasi penilaian terhadap kasus-kasus hadis tertentu bisa berbeda-beda antara masing-masing ulama menurut ijtihad dan kemampuannya dalam mengumpulkan fakta yang ada. Lihat Ibn al-Shalah,'Ulum al-Hadith, 12 
pertanyaan-pertanyaan skeptis Kamaruddin Amin tentang riwayat Abu al-Zubair dari jalur al-Laith bin Sa'd dalam perspektif metode al-Albani. Namun, hal tersebut dapat dijelaskan sebagai berikut:

a. Pendapat al-Albani yang menerima validitas riwayat Abu al-Zubair dari jalur alLaith bin Sa'd walaupun dengan cara periwayatan mu'an'an sejalan dengan pendapat ulama hadis lainnya. ${ }^{38}$

b. Dalam kaitannya dengan sighat tahammul wa al-ada', Abu al-Zubair menggunakan kata "'an" di hampir semua riyawat al-Laith yang direkam oleh para penghimpun hadis. Padahal al-Laith diklaim hanya meriwayatkan hadishadis yang didengar langsung oleh Abu al-Zubair dari Jabir. Hal ini, besar kemungkinan merupakan hasil perubahan yang dilakukan oleh para murid atau penghimpun kitab setelah adanya kepastian sama' dan informasi dari al-Laith tentang status periwayatannya dari Abu al-Zubair yang tersebar di kalangan ulama hadis. $^{39}$

c. Status Abu al-Zubair sebagai seorang mudallis secara umum tidak berubah. Akan tetapi dalam riwayat al-Laith dinegasikan dari kemungkinan tadlis walaupun menggunakan sighat 'an dalam periwayatannya karena adanya petunjuk lain di luar sanad dari kitab-kitab rijal al-hadith yang menginformasikan seleksi riwayat sama' oleh al-Laith sebagai murid dari riwayat gurunya tersebut. ${ }^{40}$

\section{Penutup}

Kritik Kamaruddin Amin terhadap metode al-Albani dalam menentukan otentitas hadis mudallas tidak seluruhnya tepat. Demikian pula, implikasi ‘metode alAlbani dalam menyeleksi validitas hadis para mudallisin yang bisa berdampak pada pendha'ifan banyak hadis adalah klaim kurang tepat dan terlalu jauh. Penelitian yang lebih komprehensif membuktikan bahwa al-Albani mengakuivaliditas hadis mu'an'an jika terdapat sighat al-sama' dari jalur lain atau jika hadis tersebut

${ }^{38}$ Ibn Hajar al-Asqalani, al-Nukat 'ala Kitab Ibn al-Shalah, Vol. 2, tahqiq Dr. Rabi' bin Hadi (Madinah: Ihya' al-Turath al-Islami, cet. 1, 1404 H/1984 M), 631. Hal ini sudah dijelaskan di halaman sebelumnya.

39 Al-Laith melaporkan,"Saya datang kepada Abu al-Zubair dan dia menyodorkan saya dua buku. Saya bimbang dengan buku tersebut dan saya bertanya kepadanya, apakah ia mendengarnya dari Jabir atau tidak. Dia berkata, "Saya mendengarnya langsung darinya sebagian dan saya diceritakan (oleh orang lain) sebagian". Saya berkata. "Ceritakanlah kepadaku apa yang engkau mendengarnya langsung". Kemudian dia menceritakan "yang saya miliki ini”. Al-Dzahabi, Siyar A'lam al-Nubala', vol. 5 (Beirut : Muassasah al-Risalah, cet. 3, 1405 H/1985 M), 382

${ }^{40}$ Al Dzahabi, Mizan al-I'tidal fi Naqd al-Rijal, ed. 'Ali Muhammad al-Bajawi, Vol. 5 (Beirut: Dar al-Ma'rifah, cet.1, 1382 H/1963 M), 380, Ibn Sa’ad, At-Tabaqat al-Kubra. Vol. 6, ed. Ali Muhammad Umar (Kairo: Maktabah al-Khanji, cet. 1, 1421 H/2001 M), 30 
$\underline{\text { Tajdid: Jurnal Pemikiran Keislaman dan Kemanusiaan }}$

Vol. 3 No. 2 Oktober 2019

memiliki mutaba'at dan syawahid dan qarinah tertentu yang mengafirmasi kesahihannya baik secara sanad maupun matan.

\section{DAFTAR PUSTAKA}

al-'Aizuri, Abdurrahman bin Muhammad. Juhud al-Albani fi al-Hadith Riwayatan wa Dirayatan. Riyad: Maktabah al-Rushd, Cet. 1, $1425 \mathrm{H}$

al-Albani, Abu 'Abd al-Rahman Nasr al-Din. Tamam al-Minnah fi al-Ta'liq 'ala Fiqh al-Sunnah, Vol. 1. T.tp: Dar al-Rayah, cet.5, t.th

, al-Ta'liqat al-Hisaan 'ala Sahih Ibn Hibban wa Tamyiz Saqimih min

Sahiihih wa Shadh min Mahfuzih, vol.1. Jeddah: Dar Ba Wazir li al-Nashr wa alTawzi', cet.1, $1424 \mathrm{H} / 2003 \mathrm{M}$ , Irwa' al-Ghalil fi Takhrij Ahadith Manar al-Sabil,Vol. 3. Beirut: al-Maktab al-Islami, cet. 2, $1405 \mathrm{H} / 1985 \mathrm{M}$

, Silsilah al-Ahadiith al-Da'ifah wa al-Mawdu'ah wa Atharuha al-Sayyi fi al-Ummah, vol. 11. Riyadh: Dar al-Ma'arif, cet.1, 1412 H/1996 M

, Silsilah al-Ahadith al-Shahihah wa Shai' min Fiqhiha wa Fawa'idiha, vol. 1. Riyadh: Maktabah al-Ma'arif, cet.1, 1415 H/1995 M

al-Juda'I, Abdullah bin Yusuf.Tahrir 'Ulum al-Hadith, Vol. 2. Beirut: Muassasah alRayyan, cet. 1, 1424 H/2003 M.

al-Khalaf, Awwad.Riwayat al-Mudallisin fi Shahih al-Bukhari: Jam'uha-Takhrijuhaal-Kalam 'alaiha. ttt: Dar al-Basyair al-Islamiyah, tt.

Al-Dzahabi.Mizan al-I'tidal fi Naqd al-Rijal, ed. 'Ali Muhammad al-Bajawi, Vol. 5. Beirut: Dar al-Ma'rifah, cet.1, 1382 H/1963 M ,Siyar A'lam al-Nubala', vol. 5. Beirut : Muassasah al-Risalah, cet. 3, 1405 H/1985 M.

al-Shaibani, Muhammad bin Ibrahim.Hayah al-Albani wa Atharuh wa Thana al'Ulama 'alaih. t.tp: Maktabah al-Saddawi, cet. 1, $1407 \mathrm{H}$

Amin, Kamaruddin.Menguji Kembali Keakuratan Metode Kritik Hadis. Jakarta: Penerbit Hikmah, Cet. 1, 2009

.Nasiruddin Al-Albani On Muslim's Sahlh: A Critical Study Of His Method. Jurnal Islamic Law And Society 11,2 Koninklijke Brill Nv, Leiden, 2004

.The Reliability of hadith Transmission - A Reexamination of Hadith-Critical Methods. Ph. D dissertation, Bonn Universitaet, 2005

Hadi, 'Isam Musa.al-Rawd al-Dani fi al-Fawa'id al-Hadithiyah li al-'Allamah Nashir al-Din al-Albani. Omman: al-Maktabah al-Islamiyah, cet.1, $1423 \mathrm{H}$

Ibn Hajar.al-Nukat 'ala Kitab Ibn al-Shalah, Vol. 2, tahqiq Dr. Rabi' bin Hadi Madinah: Ihya' al-Turath al-Islami, cet. 1, 1404 H/1984 M

Ibn Sa'ad, At-Tabaqat al-Kubra. Vol. 6, ed. Ali Muhammad Umar. Kairo: Maktabah al-Khanji, cet. 1, $1421 \mathrm{H} / 2001 \mathrm{M}$

Ibrahim, Abu al-Shadi.al-Ikhtiyarat al-Fiqhiyyah li al-Imam al-Albani. Kairo; Dar alGhadd al-Jadid, Cet.1, 1427 H/2006 M

Idri, Studi Hadis. Jakarta: Kencana Predana, cet. 2, 2013 
Muslim bin al-Hajjaj, al-Jami' al-Sahih, ed. Fu'ad Abd al-Baqi. Dar al-Kutub al'Arabiyyah, 1374 H/1955 M

Qadir, Abu Yahya Zakariya bin Ghulam.Al-Albani wa Manhaj al-Aimmah alMutaqaddimin fi 'Ilm al-Hadith. Riyadh: Maktabah al-Ma'arif, cet.1, 1431 $\mathrm{H} / 2010 \mathrm{M}$

Kamaruddin Amin, "Problematika Ulumul Hadis Sebuah Upaya Pencarian Metodologi Alternatif', dalam://www.ditpertais.net/annualconference/ancon06/makalah

/Makalah\%20Komaruddin.doc. (27 Desember 2014) dan http://profkamaruddin.blogspot.co.id/p/blog-page_2.html (diakses 25/09/2015)

,Western Methods Of Dating Vis-à-vis Ulumul Hadis", dalam http://www.uin-alauddin.ac.id/uin-982-.html (29 Desember 2014)

Latifah Ulfa, "Lebih Dekat dengan Dr Phil Kamaruddin Amin MA", 23 Juni 2010 dalam http://uin-alauddin.ac.id/uin-415-.html. Diakses 27 November 2016, 